Agro-Science Journal of Tropical Agriculture, Food, Environment and Extension Volume 14 Number 2 May 2015 pp. $9-17$

ISSNIII9-7455

\title{
PROXIMATE AND ANTI-NUTRITIONAL COMPOSITION OF LEAVES AND SEEDS OF MORINGA OLEIFERA IN NIGERIA: A COMPARATIVE STUDY
}

\author{
${ }^{1}$ Stevens, C. G., ${ }^{2}$ Ugese, F. D., ${ }^{3}$ Otitoju, G. T. and ${ }^{1 *}$ Baiyeri, K. P. \\ ${ }^{1}$ Department of Crop Science, University of Nigeria, Nsukka, Nigeria \\ ${ }^{2}$ Department of Crop Production, University of Agriculture, PMB 2373 Makurdi, Nigeria \\ ${ }^{3}$ Department of Home Science, Nutrition and Dietetics, University of Nigeria, Nsukka, \\ Nigeria \\ "Corresponding author: paul.baiyeri@unn.edu.ng
}

\begin{abstract}
Proximate and anti-nutrient composition of the leaves and seeds of ten provenances of Moringa oleifera from parts of Nigeria, were examined at Nsukka, Nigeria in 2012. Results indicated absence of significant main effect on any of the proximate traits evaluated while protein content responded significantly to plant part, showing greater accumulation in the leaves. All anti-nutritional traits considered were significantly $(p \leq 0.05)$ influenced by accession. The accession from Kolo had the highest values of oxalate, phytate and tannin but recorded lowest amounts of alkaloids. The lowest values of oxalate, phytate and tannin were from Rini, Mayo-Belwa and Awo-Garaji respectively. Saponin varied from a low of $2.46 \%$ (Awo-Garaji) to a high of $3.42 \%$ (Giri). Plant part significantly influenced all evaluated anti-quality factors except phytate and tannin. Accumulation of anti-nutrients was higher in the seeds than in the leaves except for alkaloids and flavonoids. Biplot graphs indicated more clearly the pattern of association between evaluated traits and accessions. It was quite evident that while the leaves are generally more endowed with proximate attributes and lower quantities of anti-nutrients, variations in accumulation of the anti-nutrients with specific accession could indicate genetic differences that could be exploited for breeding purposes. Besides, lower anti-nutrients in leaves than seeds suggested better bioavailability of nutrient it contained and should be more preferred for consumption than seeds.
\end{abstract}

Keyword Accession, Moringa oleifera, Proximate traits, Anti-nutrients

\section{INTRODUCTION}

Proximate composition of a food substance is, among others, critical to an understanding of the usefulness of such food material in human and animal nutrition. Such studies have therefore been carried out in a number of indigenous species. Hoe and Siong (1999) explored the nutritional content of indigenous plants of Sarawak, Malaysia. Their results indicated that in many respects, indigenous species were comparable or even superior to commonly cultivated introduced species. Glew et al., (1997) assessed the nutritional content of 24 indigenous plants of Burkina Faso and found that on dry weight basis 3 of the species had protein content in the range of $20-37 \%$ while 7 had more than $20 \%$ fat. Generally, many of the species studied were endowed with minerals, fatty acids and amino acids. In Nigeria, nutritional study of shea, a prominent indigenous species was carried out with impressive result (Ugese et al., 2008). For less known and underutilized species, such studies are particularly helpful at highlighting their food value and therefore encouraging their ultimate utilization in diverse ways.

Conversely, anti-nutrients are natural compounds occurring in plant parts which limit their food value by limiting digestion or absorption when consumed (Prathibha et al., 1995). These compounds may not necessarily be toxic (Apata and Babalola, 2012) but gives concern for human and animal health as their interference with digestion and absorption could trigger nutrient deficiencies (Prathibha et al., 1995 ) with negative consequences on health and 
productivity. In plants, numerous anti-nutrients are found. The types and concentrations of these anti-nutritional factors seem to vary with species and plant part concerned. In roots and tubers, the most commonly studied anti-nutrients include cyanogenic glycosides, saponin, phytate, oxalate, enzyme inhibitors and alkaloids (Apata and Babalola, 2012). The anti-nutrients found in Moringa oleifera are lower compared with those found in some other leafy vegetables (Noonan and Savage 1999; Radek and Savage, 2008). Besides, amylase and protease inhibitors are altogether absent in the leaves of this species (Ferreira et al., 2008). Moringa oleifera is a popular plant species globally. This is owing to its usefulness as a food, medicinal, and aesthetic plant (Fuglie, 1999). The use of the seed in water purification (Holmes et al., 1994) and the potential industrial utilization of its different plant parts and products have weighed heavily in its favour. The surpassing food value of this species is often celebrated. However, like other plant species, the presence of anti-nutritional factors in this important species is capable of reducing the bioavailability of nutrients contained in the different parts. Makkar and Becker (1996) have reported on the presence of total phenols, tannins, saponins, phytate, lectins, cyanogenic glucoside and glucosinolate in different parts of Moringa oleifera. Similarly, Sallau et al., (2012) examined the effect of various processing methods on anti-nutrient content of Moringa leaves.

Although anti-nutritional factors are generally understood to play negative roles by chelating the nutrients and forming a biding factor with the food values thereby making the nutrients non-bioavailable in the system, it is worth remarking that they also have beneficial effects at certain levels. Soetan and Oyewole (2009) have ascribed certain pharmacological effects, such as antimicrobial and anti-parasitic properties, to these secondary metabolites. Saponins are cytotoxic but are also instrumental in lowering cholesterol levels (Price et al., 1987). It also decreases the risk of cancer, dental caries, and platelet aggregation and lowers blood glucose response (James et al., 2008).

In Nigeria, an elaborate assessment of the nutritional and anti-nutritional qualities of Moringa oleifera germplasm has not been done. Such studies, among others, provide a solid basis for genetic improvement of a species as well as evolution of sound strategies for food value enhancement. The present study considered nutritional and anti-nutritional traits among 10 accessions of the species across the country. These were selected out of more numerous collections as they showed more promise in the traits of interest.

\section{MATERIALS AND METHODS}

In 2011, ripe pods of Moringa oleifera were collected from the following locations across Nigeria: Borno State (Maiduguri), Adamawa State (Mayo-belwa and Yola), Kebbi State (Rini), Nassarawa State (Kolo), Federal Capital Territory (Giri), Kogi State (Awo-garaji), Benue State (Ityomu and Dooshima), and Oyo State (Idere).

Seeds obtained from the pods were grown at the Research Farm of the Department of Crop Science, University of Nigeria, Nsukka. At maturity (October, 2012), pods and leaves were harvested. Seeds extracted from the pods as well as harvested leaves were air dried before been subjected to laboratory analyses

\section{Proximate determination}

Determination of proximate attributes of milled samples was based on standard procedures as outlined by the Association of Official Analytical Chemists (AOAC, 2005). The constituents determined were moisture, ash, crude fibre, crude protein, carbohydrate and energy (Cal/100g). Samples (5g) were ovendried at $105^{\circ} \mathrm{C}$ for 5hours when constant weight was obtained to estimate moisture content. Fat was extracted from $2 \mathrm{~g}$ of sample with petroleum ether in a soxhlet apparatus while ash was estimated by incinerating $2 \mathrm{~g}$ of sample in a muffle furnace at $550^{\circ} \mathrm{C}$ for 3 hours. The microkjedahl method was used to estimate crude protein by multiplying the value of $\mathrm{N}$ by 6.25 . Crude fibre was obtained by subjecting defatted samples through a process involving boiling under reflux with a solution containing $\mathrm{H}_{2} \mathrm{SO}_{4}$, filtering and incinerating the final residue. The value for carbohydrate was determined by subtracting from 100 the summation of values of moisture, ash, crude protein, crude fat and crude fibre.

\section{Anti-nutrient determination}

Alkaloids and Flavonoids were determined using HPLC (Waters 216/616). The samples (5.0g for alkaloids and $2.5 \mathrm{~g}$ for flavonoids) were digested, centrifuged and stored in a set of plastic vials for subsequent analysis with HPLC. Saponins, tannin, phytate and oxalates were determined using spectrometer

\section{Statistical Analysis}

Analysis of variance was applied on data collected using the Genstat statistical package (GENSTAT, 2008). Where appropriate, separation of means was effected by use of FLSD at $5 \%$ probability level. 


\section{RESULTS}

Results of analysis of variance on the main effect of proximate concentrations in $M$. oleifera indicated no significant difference in all the proximate traits measured across accessions (Table 1). Carbohydrate and protein values were more than 40 and $20 \%$ respectively while fibre content was around $9 \%$. Fat content was generally low. Moisture content varied from $6.43 \%$ for Ityomu to $6.83 \%$ for Rini. The main effect of plant component (leaf and seed) on proximate concentration of Moringa revealed significant variation only in their protein content which was significantly higher in the leaves $(25.74 \%)$ than in the seeds $(22.38 \%)$. Biplot of the proximate concentration in the leaf and seed of Moringa (Fig. 1) revealed that Giri had the highest concentration of protein in the leaf as well as the highest ash content both in the seed and the leaf. Leaves of Awo-garaji and the seeds of Rini accessions had the highest percentage moisture across the accessions and plant parts. The highest concentration of fat was found in Ityomu leaves and seeds. Idere seed was the most fibrous. Giri accession rated highest among the accessions in carbohydrate concentration, which was higher in the leaves. Moisture content of seeds and leaves was better linked with the Rini and Awo-Garaji accessions respectively. The biplot analysis of the proximate composition of the ten Moringa accessions tested explained $52.7 \%$ of the total variation across the accessions.

All anti-nutritional traits considered showed significant response to accession (Table2). Alkaloids were least concentrated in the accession from Kolo, which conversely registered the highest values in 3 of the 5 anti-nutrients considered in this study namely, oxalates, phytate and tannin. The lowest values of the above 3 antinutrients were from Rini, Mayo-Belwa and AwoGaraji respectively. Saponin varied from a low of $2.46 \%$ (Awo-Garaji) to a high of $3.42 \%$ (Giri). Significant main effect of plant part was observed on all anti-nutritional traits except phytate and tannin. Apart from flavonoids and alkaloids, seeds had higher accumulations of the anti-quality factors than leaves

Table 1. Main effect of Accession and plant part on proximate traits (\%) of Moringa oleifera across Nigeria

\begin{tabular}{lcccccc}
\hline Accession & Ash & Carbohydrate & Fat & Fibre & Protein & Moisture \\
\hline Maiduguri & 4.12 & 44.89 & 0.18 & 9.96 & 23.99 & 6.64 \\
Mayo-Belwa & 4.50 & 45.00 & 0.19 & 9.69 & 23.99 & 6.63 \\
Yola & 3.91 & 43.86 & 0.19 & 9.55 & 23.68 & 6.54 \\
Rini & 4.16 & 43.86 & 0.20 & 9.44 & 23.23 & 6.83 \\
Kolo & 4.06 & 43.73 & 0.17 & 9.83 & 23.21 & 6.46 \\
Giri & 4.71 & 46.69 & 0.20 & 9.87 & 25.23 & 6.68 \\
Ityomu & 4.74 & 45.32 & 0.19 & 9.56 & 24.41 & 6.43 \\
Dooshima & 4.20 & 45.22 & 0.19 & 9.80 & 24.40 & 6.64 \\
Awo-Garaji & 4.08 & 45.98 & 0.19 & 10.25 & 24.75 & 6.72 \\
Idere & 4.29 & 44.78 & 0.18 & 9.94 & 23.76 & 6.61 \\
LSD $(0.05)$ & NS & NS & NS & NS & NS & NS \\
Plant part & & & & & & \\
Leaves & 4.07 & 46.77 & 0.16 & 10.59 & 25.74 & 6.2 \\
Seeds & 4.48 & 43.09 & 0.21 & NS & 0.84 & NS \\
LSD(0.05) & NS & NS & NS & & & \\
\hline NS-N0 & & & & & \\
\hline
\end{tabular}

NS - No significant difference 


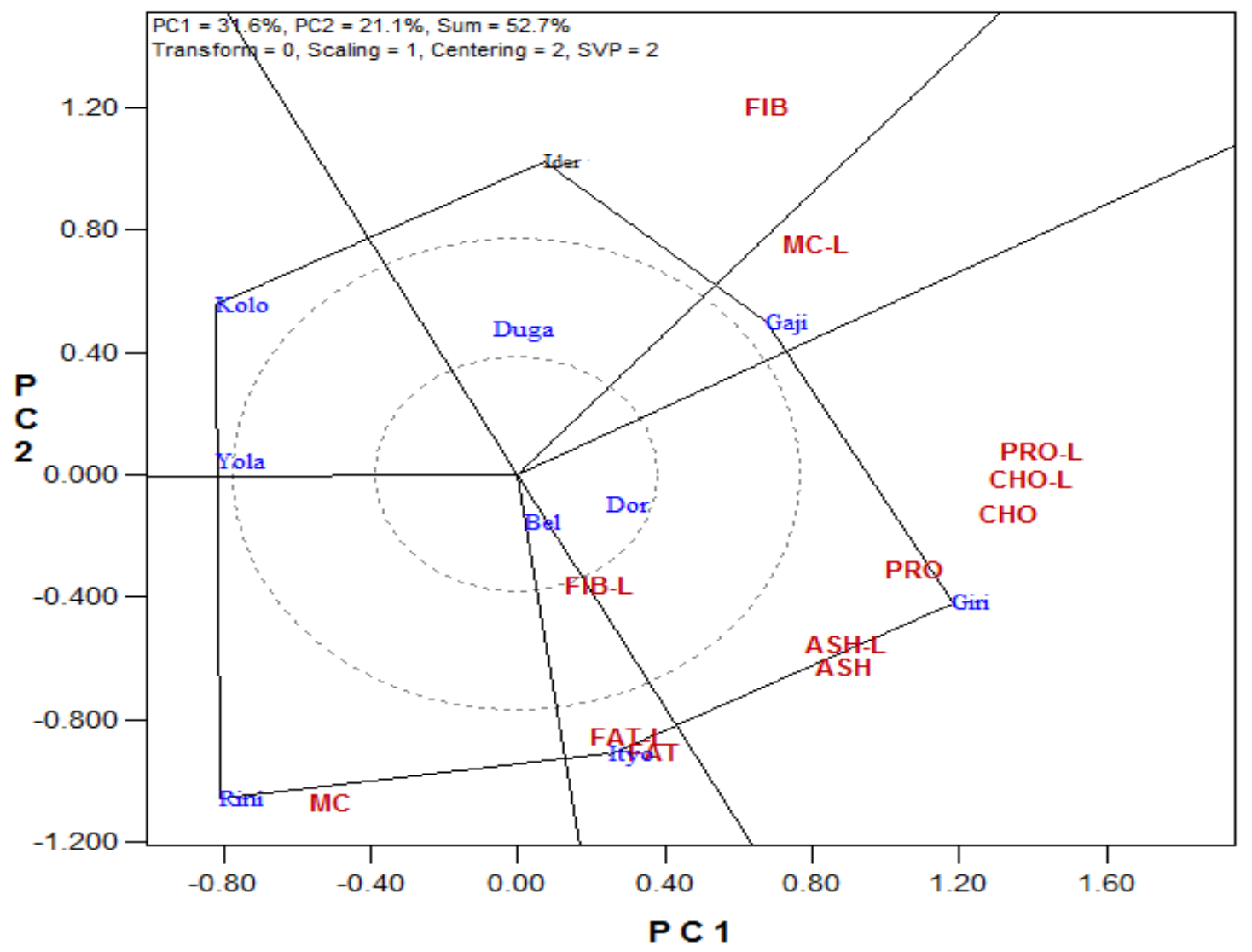

Which wins where or which is best for what

Fig 1: Biplot analysis of proximate contents of the leaves and seeds of ten accessions of Moringa oleifera

Proximate traits code: CHO, PRO, FAT, ASH, FIB, MC - Carbohydrate, protein, fat, ash, fibre, moisture content of the seed; CHOL, PRO-L, FAT-L, ASH-L, FIB-L, MC-L - Carbohydrate, protein, fat, ash, fibre, moisture content of the leaf

Accession code: Bel: Mayo-Belwa; Dor: Dooshima; Duga: Maiduguri; Gaji: Awo-Garaji; Giri: Giri; Ider: Idere; Ityo: Ityomu; Kolo: Kolo; Yola: Yola.

A biplot of the proximate traits (Fig. 1) showed that the accession from Giri had better protein and carbohydrate attributes of the seeds and leaves while that of Ityomu was remarkable in fat content. Moisture content of seeds and leaves was better linked with the Rini and Awo-Garaji accessions respectively. In contrast, Mayo-Belwa, Awo-Garaji, Rini, Ityomu and Dooshima had similar anti-nutritional traits (Fig. 2). The accession from Maiduguri was particularly pronounced in phytate, flavonoid and tannin content of seeds while Idere and Giri were associated with high leaf alkaloid content and saponin content of seeds and leaves. The biplot analysis of the anti-nutrients explained $89.4 \%$ of the total variation among the accessions.

The dendrogram in Fig. 3 shows the classification of ten accessions of M. oleifera (based on anti-nutrient concentration in their leaves and seeds) into three clusters namely: Cluster A; Idere and Giri accessions, Cluster B; Mayo-belwa, Rini, Dooshima, Ityomu and Awogaraji. Cluster $\mathrm{C}$ includes Maiduguri, Yola and Kolo accessions. 
Table 2. Main effect of Accession and plant part on anti-nutrient content (\%) of Moringa oleifera across Nigeria

\begin{tabular}{|c|c|c|c|c|c|c|}
\hline Accession & Alkaloids & Flavonoids & Oxalates & Phytate & Sapponin & Tannin \\
\hline Maiduguri & 1.77 & 5.85 & 2.21 & 3.65 & 3.07 & 2.29 \\
\hline Mayo-Belwa & 3.24 & 4.56 & 0.96 & 1.42 & 2.97 & 1.19 \\
\hline Yola & 2.18 & 6.39 & 2.05 & 3.32 & 2.87 & 2.31 \\
\hline Rini & 3.03 & 4.42 & 0.91 & 1.60 & 2.76 & 1.26 \\
\hline Kolo & 1.58 & 6.87 & 2.54 & 4.08 & 3.00 & 3.03 \\
\hline Giri & 2.53 & 4.72 & 1.69 & 2.61 & 3.42 & 2.02 \\
\hline Ityomu & 2.95 & 4.35 & 0.93 & 1.50 & 2.94 & 1.22 \\
\hline Dooshima & 3.08 & 4.33 & 0.98 & 1.49 & 3.06 & 1.29 \\
\hline Awo-Garaji & 3.17 & 4.98 & 0.98 & 1.56 & 2.46 & 1.08 \\
\hline Idere & 2.52 & 4.37 & 1.58 & 2.76 & 3.21 & 1.91 \\
\hline $\operatorname{LSD}_{(0.05)}$ & 0.66 & 0.97 & 0.62 & 0.91 & 0.46 & 0.74 \\
\hline \multicolumn{7}{|l|}{ Plant part } \\
\hline Leaves & 1.56 & 5.42 & 1.42 & 2.23 & 2.06 & 1.63 \\
\hline Seeds & 3.65 & 4.75 & 1.55 & 2.57 & 3.89 & 1.89 \\
\hline $\operatorname{LSD}_{(0.05)}$ & 0.29 & 0.43 & 0.28 & ns & 0.21 & ns \\
\hline
\end{tabular}

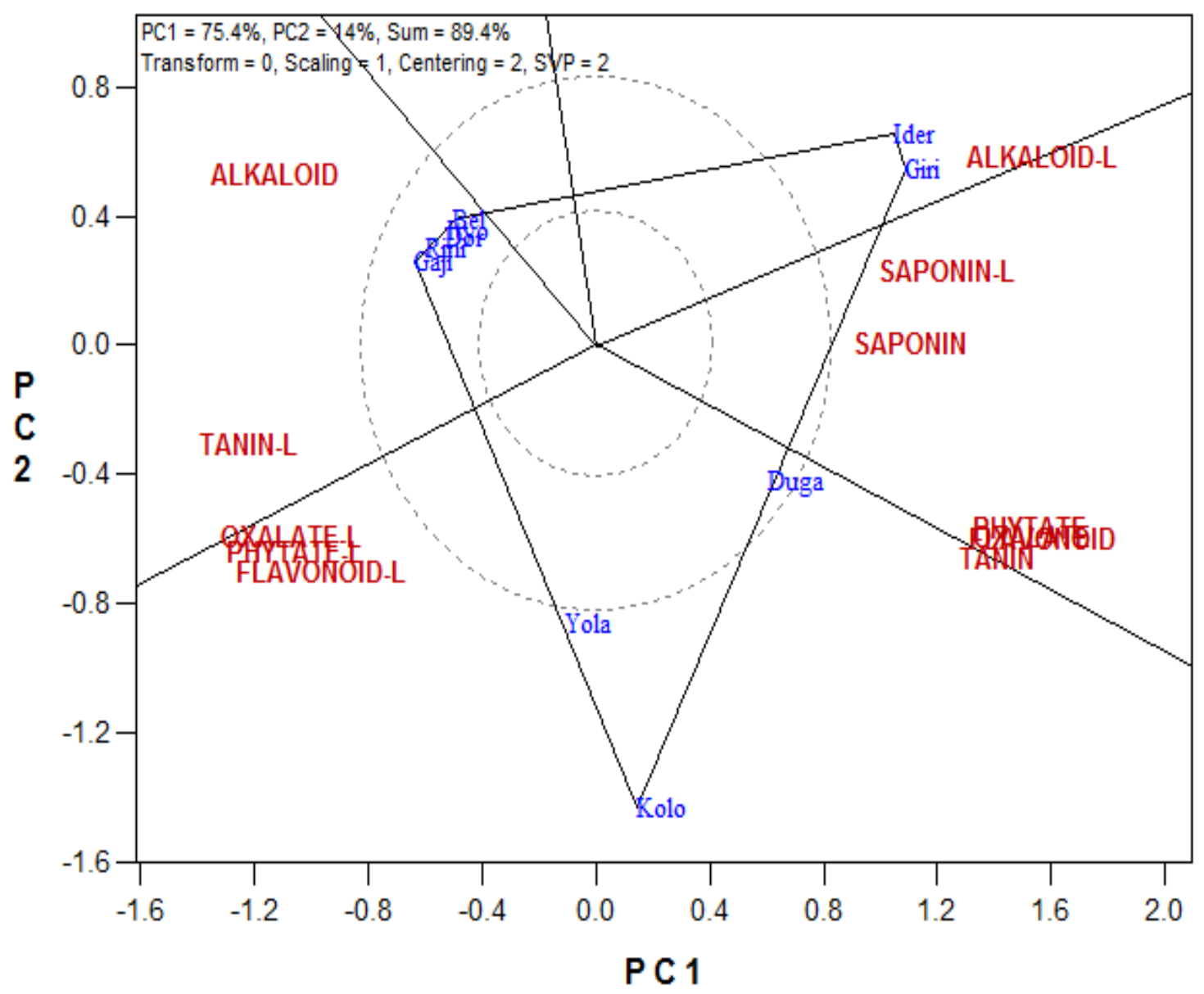

Which wins where or which is best for what

Fig. 2: Biplot analysis of antinutrient contents of the leaves and seeds of ten accessions of Moringa oleifera

Antinutrients code: ALKALOID, OXALATE, PHYTATE, SAPONIN, TANIN; Antinutritional factors of the seed; ALKALOID-L, OXALATE-L, PHYTATE-L, SAPONIN-L, TANIN-L - Antinutritional factors of the leaf.

Accession code: Bel: Mayo-Belwa; Dor: Dooshima; Duga: Maiduguri; Gaji: Awo-Garaji; Giri: Giri; Ider: Idere; Ityo: Ityomu; Kolo: Kolo; Yola: Yola. 


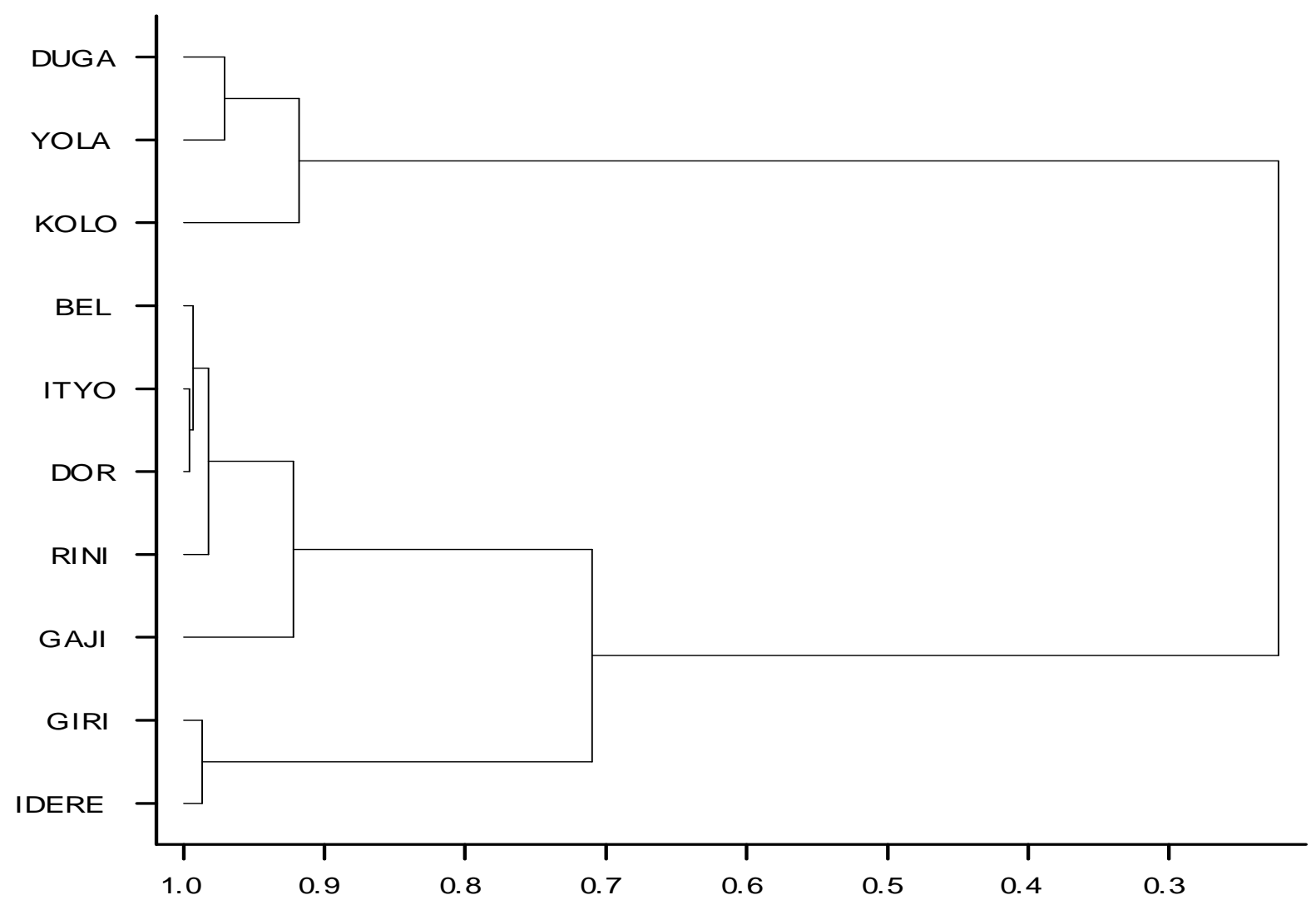

Fig. 3: Dendrogram showing the classification of 10 accessions of $M$. oleifera based on anti-nutrient concentration in the seeds and leaves.

Bel: Mayo-Belwa; Dor: Dooshima; Duga: Maiduguri; Gaji: Awo-Garaji; Giri: Giri; Ider: Idere; Ityo: Ityomu; Kolo: Kolo; Yola: Yola.

\section{DISCUSSION}

Accession did not show significant effect on any of the proximate traits denoting profound uniformity in the proximate qualities of Nigerian moringa germplasm. Yang et al., (2006) who worked with ten Moringa accessions observed only small variations in nutrient contents among them. Results however contrast with those obtained in shea (Ugese et al., 2008) where significant variations in proximate values were obtained across sampled locations. The lack of variability in proximate traits of the plant is suggestive that it can be sourced from different parts of the county with the hope of obtaining desirable results.

Generally leaves were found to accumulate more protein than seeds. It is noteworthy the high protein content of moringa leaves which in this work was found to be $25.7 \%$. This value is higher than the value of $17.01 \%$ and $23 \%$ reported by Ogbe and Afiku (2012) and Makkar and Becker (1997) respectively, comparable to the $27.44 \%$ reported by Olugbemi et al., (2010) but lower than the $30.65 \%$ obtained by Mutayoba et al., (2011). The carbohydrate value of $46.8 \%$ obtained in this study appears lower than the $63.11 \%$ reported by Ogbe and Afiku (2012) but the fibre content $(10.6 \%)$ was higher than theirs (7.09\%). Bamishaye et al., (2011) and Price (2007) obtained carbohydrate values of 55.1 and $38.2 \%$ respectively. It is obvious that the proximate properties of moringa, coupled with its other nutritional traits such as the complete set of the essential amino acids (Mathur, 2005) serves to justify its recognition as a potential solution to nutritional problems in developing countries (Tesfay et al., 2011).

The protein content of Moringa oleifera rates it the most nutritive of the four Moringa species in Africa, namely $M$. stenopetala, M.peregrina and M. drouhardii (Yang et al., 2006). The high levels of carbohydrate and fibre in the leaves of the plant could further enhance its nutritional competence. Thus while carbohydrates are expected to supply calories, fibre would expectedly furnish a lot of other benefits. This includes lowering blood cholesterol, aiding bowel movement and reducing the risk of cancer (ENCARTA, 2005). Low fibre content has been associated with constipation, obesity and heart diseases (Ajayi et al., 2014).

The remarkable nutritional profile of moringa leaf presents an attractive option not just in human nutrition but also in livestock feeding. For 
instance different levels of inclusion of the leaf in poultry feeds have been experimented with excellent results. Onu and Aniebo (2011) found that Moringa oleifera leaf meal could be included in broiler diets up to $7.5 \%$ without any deleterious impact on bird performance and blood characteristics. However, Gadzirayi et al., (2012) observed that as high as $20 \%$ inclusion of Moringa oleifera leaf meal as protein supplement produced broilers with similar weight and growth rate as those fed conventional commercial diets. This demonstrates the great potential in this plant in boosting animal production. The main cost component in livestock production is feed (Apata and Babalola, 2012). With up to $20 \%$ inclusion feed costs are sure to be considerably lowered thereby assisting to provide animal protein at affordable cost.

Furthermore, feeding of moringa leaf meal to broilers appears to have direct positive impact on health. Inclusion of the leaves in broiler diets (up to $3 \%$ ) enhanced immune responses and improved intestinal health of broilers by reducing the population of Escherichia coli and enhancing that of Lactobacillus in the ileum (Yang et al., 2006). According to the authors, the possibility exists for Moringa oleifera as a bioceutical agent to replace conventional antibiotics in broiler production. New castle disease of poultry has been effectively treated with Moringa leaf extract (Eze et al., 2012).

In contrast to what happened with the proximate qualities, anti-nutritional factors varied remarkably across accessions. This could point to a strong influence of environmental factors in the formation or production of the anti-nutrients. In the case under study, most of the anti-nutrients had their highest concentration in the accession from Kolo. This may imply that this location provided the best combination of environmental factors for the production of such anti-nutrients. The converse may be true for Awo-Garaji that produced the least values of two of the antinutrients namely, tannin and saponin. With the reported food value-depressing role of antinutritional factors, it is suggestive that although the proximate traits of the accessions did not vary remarkably, yet their available food value may not be the same owing to the presence of these factors. This may form an important consideration when sourcing for materials for use.

It is important to note that the amounts of antinutrients in moringa are generally low and do not constitute any health risks to animal or human consumers (Nouman et al. (2013)). It would appear that the lower the quantities of these antinutrients, the better. Saponins for instance, confer bitter taste on moringa without any harmful effects (Makkar and Becker, 1996). Of greater interest is the reported absence of such harmful compounds like lectins, trypsin and amylase inhibitors in moringa leaves (Ferreira et al., 2008). Oxalate salts normally result from a chemical combination between oxalic acid and a particular mineral such as $\mathrm{Ca}, \mathrm{Mg}$ or $\mathrm{Na}$ (Noonan and Savage, 1999). According to these authors (Noonan and Savage, 1999), soluble oxalates can cause kidney stones in humans and livestock, although the leaves of moringa, which are richly endowed with calcium, have a high proportion of insoluble form of oxalates, which is not linked closely with kidney stone formation. Noonan and Savage (1999) and Radek and Savage (2008) did a comparative study of the amount of oxalates present in moringa leaf and some common leafy vegetables and reported comparatively lower values of oxalates in the former, which were all in the insoluble form. On this basis, consumption of moringa appears safer than that of other common vegetables like spinach and green and purple amaranths. Since $M$. oleifera is also a browse plant (Aregheore, 2002) or has such potentials its consumption by animals may not have deleterious effects. According to Makkar and Becker (1996), the anti-nutrient concentration in Moringa oleifera is low. Its dry matter and protein digestion compares favourably with that of Leucaena sp, a commonly utilized browse plant.

The levels of phytate, oxalate and tannin we found in the seed were generally higher than levels reported by Abiodun et al., (2012). They observed, among the three anti-nutrients mentioned, greater concentrations of oxalates, followed by phytates. In our study, oxalates had the least concentration while phytates (among the 3) had the highest. Kawo et al., (2009) reported higher saponin values of $9.13 \%$ in moringa seed. The levels of phytates (2.23\%) and saponin (2.06) we observed in the leaves compared favourably with amounts of $2.57 \%$ and $1.6 \%$ respectively as reported by Ogbe and Afiku (2012). In contrast, our values of oxalates were higher than theirs. The value for tannin $(21.19 \%)$ reported by these authors appears outrageously high when compared to the $1.63 \%$ found in this study. Disparities in such values may have to do with genetic makeup, growing conditions and method of analysis (Abiodun et al., 2012).

It is noteworthy that the seeds tended to show greater concentration of anti-nutrients than leaves. It may thus be reasonable to infer that leaves ordinarily may have more food value than seeds. This argument appears sound enough when it is observed also that the leaves have higher content of protein, carbohydrates and fibre. Thus the comparatively lower values of these substances in the seeds may still have more problems with bioavailability when consumed owing to the relatively higher amounts of anti-quality factors. This is informative in that those considering the 
seed for nutritional purposes must also consider more seriously the use of processing techniques capable of eliminating or drastically reducing the amounts of these anti-nutrients. In the case of moringa leaves, various techniques have been employed with effectiveness in reduction of evaluated anti-nutrients in the following order: boiling > simmering>blanching (Sallau et al., 2012). Other methods include soaking, fermentation, germination or malting (Frutos et. al., 2004) and roasting (Mbah et al., 2012).

The comparatively higher amounts of anti-nutrients in the seeds rather than the leaves may explain why Moringa seeds are used more in ethno-medicine than the leaves. Most antinutrients are used in the cure or control of diseases. Saponin is used as an anti-biotic (Ajayi et al., 2014) and for the reduction of high blood pressure (Price, et al., 1987). Flavonoids are said to be present at all stages of growth of the plant and their presence is thought to confer on the leaves their medicinal properties (Sallau et al., 2012). They evoke mechanisms that work against survival of cancer cells and tumours (Williams et al., 2004) and act as anti-oxidants that trap free scavenging radicals in the body implicated in most diseases (Tapas et al., 2008). The tannin content compares favourably with that of two medicinal plants Senna alata (4.56\%) and Cajanus cajan (3.87\%). Phytate in Moringa is in line with that of Vignia unguiculata (2.0-2.9\%), Cajanus cajan (2.0-2.4\%) and Sphenostylis stenocarpa $(2.4 \%)$.

The dendogram suggested 3 distinct accessional groupings based on antinutrients. The groupings however did not follow any geographic pattern. Saini et al., (2013) evaluated a number of moringa cultivars in India. Based on genetic characteristics, they were grouped into 4 subclusters, which did not follow any recognizable geographical pattern. The authors opined that spread of planting material and high rates of gene flow through cross-pollination might be responsible. Results of this study indicate lack of significant variation in proximate qualities of Nigerian $M$. oleifera germplasm and have also shown that the leaves, which have lower amounts of anti-nutrients, are also more nutritionally endowed.

\section{REFERENCES}

Abiodun O. A., Adegbite J. A., and Omolola, A. O. (2012). Chemical and physicochemical properties of moringa flours and oils. Global J. Sci. Frontier Res. 12: Version 1. 7pp.

AOAC, (2005). Official method of Analysis 17th ed. Association of Analytical Chemists, Washington D.C.
Apata, D. F. and Babalola, T. O. (2012). The use of cassava, sweet potato and cocoyam and their by-products by non-ruminants. International Journal of Food Science and Nutrition Engineering 2: 54-62

Ajayi, O. B., Akomolafe, S. F. and Adefioye, A. (2014). Proximate analysis, mineral contents and phytochemical screening of Brachystegia eurycoma Harms and Piper guinense schm and Thonn. American J. of Food and Nutrition,

Aregheore, E. M. (2002). Intake and Digestibility of Moringa oleifera - batiki grass mixtures for growing goats. Small ruminant research 46: 23-28.

Bamishaiye, E. I., Olayemi, F. F., Awagu, E. F. and Bamishaiye, O.M. (2011).

Proximate and Phytochemical composition of Moringa oleifera at Three stages of Maturation. Advance Journal of Food Science and Technology, 3 (4): 233.

ENCARTA, 2005. Microsoft Encarta Encyclopedia Standard, 2005

Eze, D. C., Okwo, E. C., Okoye J.O.A., Onah, D. N. and Shoyinka, S.V.O. (2012).

Effects of Moringa oleifera methanolic leaf extract on the morbidity and mortility of chickens experimentally infected with Newcastle disease virus (Kudu 113) strain. J. Med.Plant Res. 6 (27): 4443-4449.

Fuglie, L. J. (1999). The miracle tree: Moringa oleifera: Natural nutrition for the tropics. Church World Service, Dakar, 68pp.

Frutos, P., Hervas, G., Giraldez F. G. and Mantecon A.R. (2004). Review: Tannins and Ruminant Nutrition. Spanish J. of Agricultural Research 2 (2): 191- 202.

Gadzirayi, C. T., Masamha, B., Mupangwa, J. F. and Washaya, S. (2012). Performance of broiler chickens fed on mature Moringa oleifera leaf meal as a protein supplement to soyabean meal. International Journal of Poultry Science 11: $5-10$

GENSTAT. 2008. Genstat 7.22.0 Release 3 DE Discovery Edition, Lawes Agricultural Trust, Rothmanisted Experimental Station, UK

Glew, R. H., Vanderjagt, D. J., Lockett, C., Grivetti, L. E. Smith, G. C., Pastuszyn, A. and Millson, M. (1997). Amino acid, fatty acid and mineral composition of 24 indigenous plants of Burkina Faso. Journal of Food Composition and Analysis 10:205-217.

Hoe,V B and Siong,K H. (1979). The nutritive value of indigenous fruits and vegetables 
in Sarawak. Asia Pacific Journal of Clinical Nutrition 8:24-31.

Holmes, R. G. H., Travis, V. E., Sutherland, J. P. and Folkard, G. K. (1994). The use of natural coagulants to treat wastewaters for agricultural reuse in developing countries. Science Technology and Development 12: 15-23

Kawo, A. H., Abdullahi, B. A., Gaiya, Z. A., Halilu, A., Dabai, M. and Dakare, M. A. (2009). Preliminary phytochemical screening, proximate and elemental composition of

Moringa oleifera Lam seed powder. Bayero Journal of Pure and Applied Sciences 2: 96-100.

Makkar, H. P. S. and Becker, K. (1996). Nutritional value and antinutritional components of whole and ethanol extracted Moringa oleifera leaves. Animal Feed Science and Technology 63: 211-228.

Makkar, H. P. S. and Becker, K. (1997). Nutrients and antiquality factors in different morphological parts of the Moringa oleifera tree. Journal of Agricultural Science,

Cambridge 128: 311-322

Mbah B. O., Eme, P. E. and Paul A. E., (2012). Effect of Drying tecniques on the proximate and other nutrient composition of Moringa oleifera leaves from two areas in Eastern Nigeria. Pakistan J. of Nutrition, 11 (11): 10441048.

Mutayoba, S. K., Dierenfeld, E., Mercedes, V. A., Frances, Y. and Knight, C. D. (2011). Determination of chemical composition and anti-nutritive components for Tanzanian locally available poultry feed ingredients. International Journal of Poultry Science 10: 350-357

Noonan, S. and Savage, G. 1999. Oxalate content of food and its effect on humans. Asia Pacific Journal of Clinical Nutrition 8 : 64-74

Nouman, W., Basra, S. M. A., Siddiqut , M. T., Yasmeen, A., Gull, T. and Alcayde, M. A. C. (2013)..Potential of Moringa oleifera L. as livestock fodder crop: a review. Turkish Journal of Agriculture and Forestry 37: 1211-1266

Ogbe, A. O. and Affiku, J. P. (2012). Proximate study, mineral and anti-nutrient composition of Moringa oleifera leaves harvested from Lafia, Nigeria: Potential benefits in poultry nutrition and health. Journal of Microbiology, Biotechnology and Food Sciences 1: 296-308

Olugbemi, T. S., Mutayoba, S. K. and Lekule, F. P. (2010). Effect of Moringa (Moringa oleifera) inclusion in cassava based diets to broiler chickens. International Journal of Poultry Science 9: 363-367

Onu, P. N. and Aniebo, A. O. (2011). Influence of Moringa oleifera leaf meal on the performance and blood chemistry of starter broilers. International Journal of Food, Agriculture and Veterinary Sciences 1: 38-44

Prathibha, S., Nambisan, B. and Leelamma, S. (1995). Enzyme inhibitors in tuber crops and their thermal stability. Plant Foods for Human Nutrition 48: 247-257

Price, K. R., Johnson, I. T. and Fenwick, G. R. (1987). The chemistry and biological significance of saponins in foods and feeding stuffs. CRC Critical Reviews in Food Science and Nutrition 26: 27-135

Price, M. L. (2007). The Moringa Tree. ECHO technical 1 note. Revised edition .11 $12 \mathrm{pp}$.

Radek, M. and Savage, G. P. (2008). Oxalates in some Indian green leafy vegetables. International Journal of Food Science and Nutrition 59: 246-260

Sallau, A. B., Mada, S. B., Ibrahim, S. and Ibrahim, U. (2012). Effect of boiling, simmering and blanching on the antinutritional content of Moringa oleifera leaves. International Journal of Food Nutrition and Safety 2: 1-6

Soetan, K. O. and Oyewole, O. E. (2009). The need for adequate processing to reduce the anti-nutritional factors in animal feeds: A review. African Journal of Food Science 3: 223-232.

Tapas, A. R., Sakarkar, D.M. and Kakde, R.B. (2008). Flavonoids as Neutraceuticals: A Review Tropical J. of Pharmaceutical Research. 7(3) 1089 - 1099.

Tesfay, S. Z., Bertling, I., Odindo, A. O., Workneh, T. S. and Mathaba, N. (2011). Levels of anti-oxidants in different parts of moringa (Moringa oleifera) seedling. Afri. J. Agric. Res. 6: 5123-5132.

Ugese, F. D., Baiyeri, K. P., Mbah, B. N. (2008). Nutritional composition of she (Vitellaria paradoxa) fruit pulp across its major distribution zones in Nigeria. Fruits 63: 65-73 